\title{
O DIREITO ADMINISTRATIVO NO BRASIL
}

\author{
CARLOS S. DE BARROS JUNIOR \\ Docente Livre de Direito Administrativo na \\ Faculdade de Direito da Universidade de \\ São Paulo
}

Entre nós, madrugou o estudo do Direito Administrativo, se bem que sob a influência principal das doutrinas francesas, do primeiro período. Os nossos estudiosos acompanhavam o desenvolvimento da disciplina na Europa, pois, já em 1833, era proposta no parlamento do Império a criação da cadeira de Direito Administrativo e Ciência da Administração, em S. Paulo e no Recife.

Introduzido o seu estudo nos cursos jurídicos, em 1854, lecionaram a matéria no Recife, PEREIRA DO REGO, e, em S. Paulo, o Conselheiro RIBAS, a partir de 1855.

Os primeiros estudos da matéria foram assim, principalmente, compendios de professores, escritos para o aprendizado nas Faculdades.

O primeiro que aparece é o do professor PEREIRA DO REGO, da Faculdade do Recife, em 1858, e que teve outras edições.

Seguem-se os compendios de VEIGA CABRAL e dos professores de São Paulo, entre os quais avulta a obra de RIBAS, oficialmente adotada para uso das Faculdades de Direito de Recife e S. Paulo.

O livro do Visconde do URUGUAY - Ensaio Sobre o Direito Administrativo Brasileiro, escrito em 1862 - e o de RIBAS são os dois principais estudos da primeira fase do nosso Direito Administrativo.

Esse primeiro periodo na evolução do nosso Direito Administrativo compreende, na lição de THEMISTOCLES CAVALCANTI, "desde a proclamação da Independência, ou melhor, desde o meado do século passado, quando se começou a fazer sentir a influência das primeiras obras escritas no estrangeiro sôbre direito administrativo e quando surgiram os nossos primeiros compêndios. 
DE GÉRANDO, LAFFERRIERE, VIVIEN, CABANTOUS, MACAREL, etc. foram os nomes que exerceram maior influência sôbre os nossos estudiósos dessa disciplina, e, por isso mesmo, ficaram as obras dos nossos escritores restritas as aspectos do direito administrativo, então objeto daqueles primeiros tratados.

Não devem, porém, ser menosprezadas nem a obra legislativa, notável para aquela época, nem a considerável contribuição do Conselho de Estado".

Com efeito, há que salientar, nesse periodo, ao lado de preciósos ensaios de doutrinação, notáveis para a época, os eruditos e abalisados pareceres do Conselho do Estado, infelizmente suprimido com a República, se bem que, pela própria natureza que o tribunal teve entre nós, longe estivesse a sua influência da exercida pelo seu homônimo francês.

Proclamada a República, embora se deva assinalar certa decadência no que diz respeito às publicações da especialidade, são dignos de menção trabalhos de AMARO CAVALCANTI, o "Tratado" de VIVEIROS DE CASTRO, hoje superado como contribuição específica, os compendios de ALCIDES CRUZ, PORTO CARREIRO, as preleções de CARDOSO DE MELLO NETO, sendo de salientar, nessa primeira fase republicana, pelo valôr científico, as monográficas de RODRIGO OTAVIO, MARIO MASAGÃO, atual professor em São Paulo, MANUEL MADRUGA e alguns outros. Nada, entretanto, como nota TITO PRATES, de sistemático, como aparecerá na Argentina, na obra de BIELSA e de RODOLFO BULLRICH.

1930 marca, porém, o início do periodo de renovação dos estudos do Direito e instituições administrativas no Brasil.

As exigências de mais acentuado cunho social nas tarefas do Estado, a maior maturidade da disciplina, decorrente de aperfeiçoamento no seu tratamento doutrinário, especialmente na Alemanha, França e Itália, com as devidas repercussões entre nós, os estudos sistemáticos de racionalização dos serviços públicos levados a efeito a partir da criação do Conselho Federal do Serviço Público Civil e do Departamento Administrativo do Serviço Público - cada um de per si, foram causas de maior cuidado nos estudos da especialidade, até então, - com ressalva das exceções assinaladas - relegados a um segundo plano, pelos juristas nossos.

Renovaram-se, assim, as doutrinas do Direito Administrativo, de par, com a preocupação no aperfeiçoamento e racionalização das modernas técnicas administrativas.

Foi o que assinalou, aliás, THEMISTOCLES CAVALCANTI, neste passo do histórico que fêz do nosso Direito Administrativo, ao ponderar sobre a fase posterior a 1930, de profunda transformação. 
Publicam-se, dessa data em diante, obras sistematizadas de maior valor relativamente às do período anterior, bem como estudos monográficos, que passam a enriquecer a bibligrafia nacional sôbre o assunto.

A todos sobreleva, pela extensão e valia da contribuição trazida - se bem que se ressinta ela, exatamente, por essa primeira circunstância, de uma certa pressa na elaboração - a notável obra de THEMISTOCLES BRANDÃO CAVALCANTI, hoje, na disciplina, um nome universal.

Na sua parte principal, essa elaboração inestimável, iniciou-se com as "Instituições de Direito Administrativo Brasileiro", de 1936, e ampliou-se com o "Tratado", em 6 volumes, publicado em 19481949.

Entre as obras gerais, devem mencionar-se, pelo seu valor, as de MATTOS DE VASCONCELLOS e GUIMARÃES MENEGALE, bem elaboradas e de boa informação doutrinária.

Embora, de um modo geral, excessivamente sintético na exposição, igualmente importantes são os trabalhos do Prof. CIRNE LIMA, do Rio Grande do Sul, cuja notável cultura humanista transparece em cada uma de suas obras. Na mesma linha de valor doutrinário, podemos situar a obra dos professores MANOEL DE OLIVEIRA FRANCO SOBRINHO, do Paraná, com farta bibliografia, e ODILON C. ANDRA $D E$, de Minas Gerais.

Destaque especial deve ser dado, em São Paulo, à contribuição carreada para êstes estudos pelos notáveis administrativistas Prof. MARIO MASAGÃO, J. H. MEIRELES TEIXEIRA e TITO PRATES DA FONSECA.

Cada um deles, além de eximio especialista, caracteriza-se pelo profundo conhecimento humanista e nos vários ramos da ciência jurídica. Conta-se mesmo do primeiro, que, ao término de suas aulas costuma perguntar aos alunos: to explicado?

- alguns dos senhores têm ainda alguma dúvida sobre o pon

- alguns dos senhores têm dúvidas sôbre qualquer ponto do programa?

- alguns dos senhores têm dúvidas sôbre qualquer assunto de Direito?

E, seguro de si, aguarda a indagação que possa sobrevir...

Professor da matéria em S. Paulo, em cuja cátedra sucedeu ao Prof. VILABOIM, publicou, na especialidade, três notáveis monogra. fias, e, recentemente, claro e erudito "Curso de Direito Administrativo". 
MEREILES TEIXEIRA, dotado de capacidade e erudição incomuns, gosa, no dizer de ALCIDES GRECA, do mais justificado renome continental. Cada um de seus estudos e pareceres são mais do que monografias sôbre os temas que versa, constituem verdadeiros tra tados.

Quanto a TITO PRATES DA FONSECA, está ligado, de maneira especial, ao progresso do Direito Administrativo entre nós. Sôbre os seus textos modernos no conteúdo e na bibliografia, debruçaram-se as últimas gerações de estudiosos da disciplina no Brasil.

Avultam, dentre os seus trabalhos, os estudos que publicou, de 1935 em diante, sôbre o então novo fenômeno das autarquias, a princípio incompreendidas entre nós, dada a formação, ao tempo, predominantemente civilista, dos nossos mais notáveis cultores da ciência jurídica.

Referência especial merecem ainda, em São Paulo, os estudos brilhantes de OSWALDO ARANHA BANDEIRA DE MELO, HELY LOPES MEIRELES, FERNANDO MENDES DE ALMEIDA, ANTONIO NOGUEIRA DE SÁ, CRETELLA JUNIOR, e, fora dêste Estado, a obra notável de SEABRA FAGUNDES e dos professores CÁIO TÁCITO, BILAC PINTO, ALCINO DE PAULA SALASAR e dos demais componentes do grupo que se formou pari-passu com a contribuição inestimável que representaram e trouxeram a "Revista de Direito Administra tivo", ao progresso dos estudos e pesquizas no campo das instituições administrativas brasileiras. 